\title{
Phosphorous balance in different fertilization systems in agrocenosis of the Central Forest- Steppe
}

\author{
Demydenko O. \\ Cherkasy State Agricultural Research Station of National Institute of Agriculture of NAAS \\ 13 Dokuchaieva Str., Holodnianske village, Smila region, Cherkasy oblast, Ukraine, 20731 \\ e-mail: smilachiapv@ukr.net \\ ORCID: 0000-0002-5334- 1154
}

Goal. To give a comparative assessment of the balance of phosphorus, and to determine a connection with the productivity of cereals in the short crop rotation for long-term application of organic and organomineral fertilizer systems in the Central Forest-Steppe of Ukraine. By-products of crops were used as organic fertilizer at saturation of the crop rotation with the legume. Methods. Studies were carried out in the stationary field experiment in the Cherkasy state agricultural experimental station of NSC «Institute of agriculture of NAAS» in $2011-2019$ on the area of 0.75 ha in 5 fields with the seed size of the plot $30 \mathrm{~m} 2$, and 4-times repeatability. They used field, laboratory, comparative-calculation, and mathematical methods. Results. At the use of organic fertilizer system, a strong correlation was revealed between the output of f.u. and the main products and the rate of turnover and balance capacity of P2O5: in the first case, the opposite $(R=0.65-0.69 \pm 0.02 ; R 2=0.42-0.48)$, in the second - direct $(R=0.67-0.85 \pm 0.02 ; R 2=0.45-0.72)$. Compared to the organo-mineral fertilizer system correlation weakened somewhat. Per unit of output of f.u. and the primary product increase of the capacity of the P2O5 balance was in 1.78 and 2.11 times smaller. Between the P2O5 balance capacity and balance capacity of $\mathrm{N}$ and $\mathrm{CO} 2$ was a direct correlation on the average level: $\mathrm{R}=0.53 \pm 0.02$; $\mathrm{R} 2=0.23$ for $\mathrm{N}$, and $\mathrm{R}=0,90 \pm 0,03$; $\mathrm{R} 2=0,86$ - for $\mathrm{CO} 2$. Per unit of the capacity growth of balance of phosphorus, they fixed $7.62 \mathrm{~kg} \mathrm{~N}$ and 0.79 tons of $\mathrm{CO} 2$, which was significantly higher as compared to the organo-mineral fertilizer system. Conclusions. Assessment of dynamics of yield of grain crops in 2011 - 2019 had shown the following: in organic fertilizer system the increasing trends were detected in winter wheat and barley; in organo-mineral fertilizer system regression coefficients for the variable degree functions at the cultivation of barley were higher in 1.5-1.8 times, winter wheat - were approaching each other. Grain yields at the use of organic and organo-mineral fertilizer systems of cultivation were decreasing, at the use of organic fertilizer system, the drop in trend was in 1.9 times less.

Key words: organic fertilizer system, organo-mineral fertilizer system, turnover of phosphorus, intensity of balance, capacity of balance, winter wheat, spring barley, corn.

DOI: https://doi.org/10.31073/agrovisnyk202005-03

The phosphorus cycle in agrocenoses under different fertilization systems and different levels of intensity has a certain direction, dynamism, as well as stability and its specific state. It can be quantified using the balance of phosphorus - a kind of identification system, which indicates the existing features and measures required for stabilization and normal functioning of the phosphorus cycle under different fertilizer systems [13]. The priority macronutrients, the balance of which must be determined, include, at the level of organic carbon and nitrogen, phosphorus [4,5]. Phosphorus is one of the key elements of mineral nutrition of crops, which plays an important and central role in their metabolism [6-10]. Creating an energy basis for the functioning of plant cells, it is part of nucleic acids and nucleotides, membrane lipids, enzymes and intermediates of the photosynthetic and respiratory cycles, and therefore its assimilation and metabolism are crucial for plant growth and development. Although the initial stages are critical for phosphorus, optimal supply of them is important throughout the growing season of plants under different fertilizer systems.

Phosphorus by its chemical properties has a complex nature of interaction with soil components, which greatly complicates the objective assessment of soil availability of this element for optimal growth and development of plants under different fertilization systems, and the availability of phosphates is determined by the solubility of fertilizer reaction products. It is very important to maintain the level of phosphorus available to plants to avoid its deficiency, which in turn leads to a decrease in crop yields [11-13]. Under the influence of intensification of agricultural production, growth of crop yields and intensification of soil degradation processes that took place in the first decades of the 21st century, other agro-ecological conditions have been formed that need new criteria for evaluation and revision of existing ones. Many scientific works have been devoted to the study of the influence of fertilizer systems on the phosphorus balance in crop rotation agrocenoses [14-21]. and soy. Topicality. At the present stage of formation of organic farming the question of formation of balance of phosphorus and its influence on productivity of cultures becomes short.

Balance calculations of phosphorus were performed according to an improved method [22] of calculating the balance of nutrients in on-farm land management projects taking into account the removal of phosphorus by the main crop, and phosphorus circulation time is calculated as the ratio of phosphorus in total phytomass to vegetation consumption [22]. Generalization of research results was performed using the program STATISTICA-10 using non-parametric statistics and correlation analysis. 
1. Organic fertilizer system in 5-row grain-row crop rotation

\begin{tabular}{|c|c|c|c|c|c|c|c|c|c|c|}
\hline \multirow{3}{*}{$\begin{array}{c}\text { Crop } \\
\text { rotation crops }\end{array}$} & \multicolumn{10}{|c|}{ NRC income, $\mathrm{kg} / \mathrm{ha}$ : } \\
\hline & $\begin{array}{l}\text { inoculati } \\
\text { on }\end{array}$ & \multicolumn{3}{|c|}{ with byproducts } & \multicolumn{3}{|c|}{$\begin{array}{l}\text { On straw for } \\
\text { fertilizer }\end{array}$} & \multicolumn{3}{|c|}{$\begin{array}{c}\text { feeding with } \\
\text { biological product }\end{array}$} \\
\hline & NPK & $\mathrm{N}$ & $\mathrm{P}$ & K & $\mathrm{N}$ & $\mathrm{P}$ & K & $\mathrm{N}$ & $\mathrm{P}$ & $\mathrm{K}$ \\
\hline pea & $50 / 50 / 50$ & 22 & 8 & 47 & 87 & 57 & 18 & 50 & 50 & 50 \\
\hline $\begin{array}{l}\text { Winter } \\
\text { wheat }\end{array}$ & $50 / 50 / 50$ & 31 & 7 & 42 & 44 & 68 & 38 & 50 & 50 & 50 \\
\hline Corn & $50 / 50 / 50$ & 45 & 14 & 92 & 25 & 46 & 22 & 50 & 50 & 50 \\
\hline Soy & $50 / 50 / 50$ & 33 & 10 & 64 & 33 & 85 & 41 & 50 & 50 & 50 \\
\hline Barley & $50 / 50 / 50$ & 27 & 3 & 31 & 7 & 42 & 19 & 50 & 50 & 50 \\
\hline
\end{tabular}

* Standard consumption of mineral fertilizers for the formation of 1 ton of crop, $\mathrm{kg} / \mathrm{ha}$

Research results. The general statistical model of phosphorus content $\left(\mathrm{P}_{2} \mathrm{O}_{5}\right)$ in the structure of total phytomass for organo-mineral and organic fertilizer systems showed that the interval content is $\Delta$ max-min $=$ $20.7 \mathrm{~kg} / \mathrm{ha}$ with an average content of $33.4 \mathrm{~kg} / \mathrm{ha}$. The median value of P2O5 content is close to the average $(34.2 \mathrm{~kg} / \mathrm{ha})$, and the typical range of values is $\Delta \mathrm{L} 0.75-\mathrm{L} 0.25=7.6 \mathrm{~kg} / \mathrm{ha}$. The phosphorus content in the total phytomass averages $46.8 \mathrm{~kg} / \mathrm{ha}$ with an interval scale of $20.1 \mathrm{~kg} / \mathrm{ha}$. The content of $\mathrm{P}_{2} \mathrm{O}_{5}$ at the median value deviated slightly from the average value $(48.1 \mathrm{~kg} / \mathrm{ha})$, and the typical range of values was $\mathrm{L} 0.75-0.25=6.5$ $\mathrm{kg} / \mathrm{ha}$.

The content of $\mathrm{P}_{2} \mathrm{O}_{5}$ at the median value tends to a greater extent to the upper typical value, which indicates a tendency to increase $\mathrm{P}_{2} \mathrm{O}_{5}$ in the total phytomass. The content of $\mathrm{P}_{2} \mathrm{O}_{5}$ of the main product in the total phytomass by average and median values is $71-72 \% .28-29 \%$ of $\mathrm{P}_{2} \mathrm{O}_{5}$ from the total content in phytomass is concentrated in by-products and roots: the interval range is $\Delta$ max-min $=6.5 \mathrm{~kg} / \mathrm{ha}$, and the typical interval is $\Delta \mathrm{L} 0.75-0.25=3.7 \mathrm{~kg} / \mathrm{ha}$. The coefficients of variation of the structuring parameters of the total phytomass varied within the allowable limits of Coef $\cdot v=21.9 \%$.

The use of organo-mineral fertilizer system promotes the growth of both average and median $\mathrm{P}_{2} \mathrm{O}_{5}$ content in the main product, which increases by $9-10 \%$ or $3.4-3.9 \mathrm{~kg} / \mathrm{ha}$, respectively, the general model. The interval scope of the content is narrowed due to the increase of the minimum value of the content by 9.4 $\mathrm{kg} / \mathrm{ha}$. The typical content range for the organo-mineral fertilizer system narrows due to the increase in the values of the upper (L0.75) and lower (L0.25) typical values by $3.2-5.4 \mathrm{~kg} / \mathrm{ha}$. The average weight of the total phytomass relative to the values of the general model increased by $5.9 \mathrm{~kg} / \mathrm{ha}$, and the median weight - by $6.4 \mathrm{~kg} / \mathrm{ha}$. The interval and typed scope narrowed relative to the overall model by 1.24 and 1.39 times. The coefficient of variation of the parameters of the components of the total phytomass was Coef $\cdot v=10.3-$ $10.9 \%$ (table 2).

2. Statistical parameters of phosphorus content in the structure of phytomass of short-rotation crop rotation under different fertilizer systems (2010-2019)

\begin{tabular}{|c|c|c|c|c|c|}
\hline \multicolumn{2}{|c|}{ 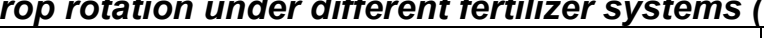 } & \multicolumn{4}{|c|}{$\mathrm{P}_{2} \mathrm{O}_{5} \mathrm{~B}(\mathrm{t} / \mathrm{ha}):$} \\
\hline \multicolumn{2}{|c|}{ 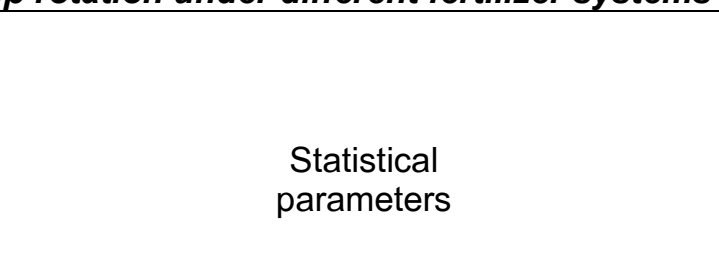 } & 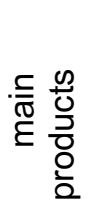 & $\begin{array}{l}\frac{0}{0} \\
\frac{0}{0} \\
\frac{0}{0} \\
\frac{1}{2}\end{array}$ & $\begin{array}{l}\stackrel{n}{0} \\
\underline{0}\end{array}$ & 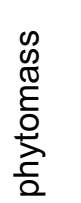 \\
\hline \multicolumn{6}{|c|}{ Organo-mineral fertilizer system (control) } \\
\hline \multirow{3}{*}{ **** Parameter } & average & 37,1 & 15,1 & 0,26 & 52,7 \\
\hline & $\min$ & 29,6 & 11,6 & 0,21 & 41,5 \\
\hline & $\max$ & 40,9 & 17,0 & 0,29 & 57,7 \\
\hline \multirow{3}{*}{ *** Quantum parameter } & Med, 0.50 & 38,1 & 15,9 & 0,28 & 54,5 \\
\hline & $L_{0.25}$ & 34,9 & 14,1 & 0,25 & 49,4 \\
\hline & $\mathrm{L} 0.75$ & 40,3 & 16,4 & 0,28 & 57,3 \\
\hline \multicolumn{2}{|l|}{ Coef. V, \% } & 10,6 & 12,0 & 10,3 & 10,9 \\
\hline \multicolumn{6}{|c|}{ Organic fertilizer system } \\
\hline \multirow{3}{*}{ **** Parameter } & average & 30,5 & 13,0 & 0,22 & 43,9 \\
\hline & $\min$ & 25,2 & 11,7 & 0,19 & 40,2 \\
\hline & $\max$ & 35,3 & 16,1 & 0,25 & 50,9 \\
\hline \multirow{3}{*}{ *** Quantum parameter } & Med, 0.50 & 30,1 & 12,2 & 0,21 & 42,5 \\
\hline & $\mathrm{L}_{0.25}$ & 28,1 & 11,8 & 0,20 & 40,9 \\
\hline & $\mathrm{L}_{0.75}$ & 33,4 & 14,0 & 0,23 & 46,7 \\
\hline \multicolumn{2}{|l|}{${ }^{*}$ Coef. V, \% } & 11,7 & 12,5 & 9,63 & 8,97 \\
\hline
\end{tabular}


Note: * Coef. $V, \%$ - coefficient of variation; ${ }^{* *}$ max-min - amplitude range; ${ }^{* * * *} \mathrm{~L} 0.75-\mathrm{L} 0.25$ - quartile scope or normalized scope.

Under the organic fertilizer system, the average and median stock of $\mathrm{P}_{2} \mathrm{O}_{5}$ in the main products relative to the intensive fertilizer system decreased by 1.22-1.27 times. The interval scope of the $\mathrm{P}_{2} \mathrm{O}_{5}$ stock was at the level of the intensive fertilizer system at lower values of the minimum and maximum stock values: 28.1-33.4 $\mathrm{kg} / \mathrm{ha}$ against $29.6-40.9 \mathrm{~kg} / \mathrm{ha}$. Similarly, a typical range of $\mathrm{P}_{2} \mathrm{O}_{5}$ stock in the main products was formed: the upper and lower typical values were lower by 1.05 and 1.22 times the value of the organo-mineral fertilizer system. If in the organo-mineral system of fertilizers the median value tended to the upper typical value, in the organic, on the contrary - to the lower typical value, which indicates the restraint of the accumulation of $\mathrm{P}_{2} \mathrm{O}_{5}$ in the main products (Table 2).

3. Statistical parameters of the phosphorus balance of short-rotation crop rotation under different fertilizer systems for 2010-2019

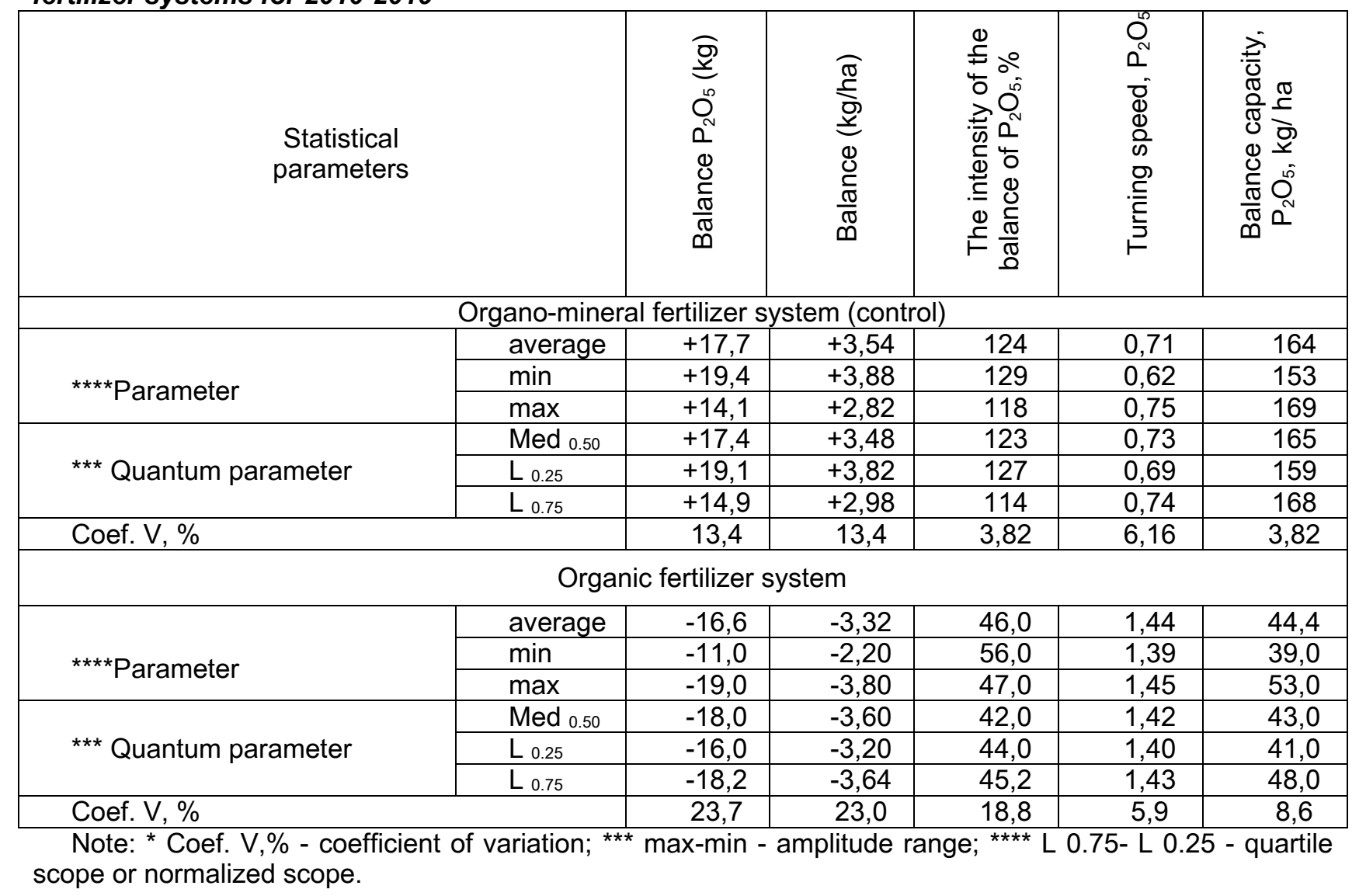

The average median stock of $\mathrm{P}_{2} \mathrm{O}_{5}$ in the total phytomass of the organic fertilizer system was lower by 1.20 and 1.35 times relative to the organo-mineral fertilizer system. The interval and typical range of $\mathrm{P}_{2} \mathrm{O}_{5}$ stock was narrower relative to the organo-mineral fertilizer system, and Coef $\bullet v$ were in the range of 8.97$12.5 \%$, which indicates the stabilization of the process of $\mathrm{P}_{2} \mathrm{O}_{5}$ accumulation in the structural elements of phytomass. The main products accounted for $69-70 \%$ of P2O5 from the accumulated stock in the total phytomass. According to the organo-mineral fertilizer system, the average phosphorus yield for all articles was $90.5 \mathrm{~kg} / \mathrm{ha}$ with an amplitude range $\Delta$ max-min $=5.6 \mathrm{~kg} / \mathrm{ha}$. The median yield was at the level of the average value $(91.0 \mathrm{~kg} / \mathrm{ha})$, and the typical interval range was $\Delta \mathrm{L} 0.75-0.25=2.4 \mathrm{~kg} / \mathrm{ha}$, which indicates a stabilization in time of $\mathrm{P}_{2} \mathrm{O}_{5}$ entry into the balance circulation of phosphorus in crop rotation.

The income of $\mathrm{P}_{2} \mathrm{O}_{5}$ due to the lateral, aboveground and root phytomass was $17-18 \%$ of the total income of both average and median values and amounted to $15.6-16.3 \mathrm{~kg} / \mathrm{ha}$. The value of the receipt of $\mathrm{P}_{2} \mathrm{O}_{5}$ for this article by the median tended to the upper typical value, which indicates a growing trend of a positive article $\mathrm{P}_{2} \mathrm{O}_{5}$.

The balance of $\mathrm{P}_{2} \mathrm{O}_{5}$ on the average and median values was positive at the level of $+17.4-17.5 \mathrm{~kg} / \mathrm{ha}$. The interval and typical scope were narrowed, which indicates the stability of the $\mathrm{P}_{2} \mathrm{O}_{5}$ balance in crop rotation under the organo-mineral fertilizer system. The balance capacity of the organo-mineral fertilizer system was $164-165 \mathrm{~kg} / \mathrm{ha}$, and the interval amplitude and normalized range of values was $\Delta \max -\mathrm{min}=16.0$ $\mathrm{kg} / \mathrm{ha}$ and $\Delta \mathrm{L} 0.75-0.25=9.0 \mathrm{~kg} / \mathrm{ha}$. The coefficient of variation was at the level of Coef $\cdot v=3.82 \%$, which indicates the stability of the balance capacity over the years of research. The turnover rate of $\mathrm{P}_{2} \mathrm{O}_{5}$, which was determined by the ratio of $\mathrm{P}_{2} \mathrm{O}_{5}$ content in the total biomass to the consumption of $\mathrm{P}_{2} \mathrm{O}_{5}$ during the growing season $(\mathrm{B})$, was $<1.0$, which indicates a high level of circulation. Amplitude and normalized interval values of $\mathrm{P}_{2} \mathrm{O}_{5}$ turnover rate were $\Delta \max -\mathrm{min}=0.13 \mathrm{~kg} / \mathrm{ha}$ and $\Delta \mathrm{L} 0.75-0.25=0.05 \mathrm{~kg} / \mathrm{ha}$, which indicates the intensive circulation of $\mathrm{P}_{2} \mathrm{O}_{5}$ at low values of Coef $\bullet v<10,0$. The values of the balance intensity (IBsr $\left.=0.5\right)$ 
significantly exceeded $100 \%$, which confirms the conclusion about the high level of $\mathrm{P}_{2} \mathrm{O}_{5}$ circulation in the agrocenosis of short-rotation crop rotation during 8 years of research (Table 3 ).

Under the organic fertilization system, the yield of $\mathrm{P}_{2} \mathrm{O}_{5}$ on all balance sheet items was 6.5 times lower than the average value and 7.2 times lower than the median value. The amplitude range was $4.4 \mathrm{~kg} / \mathrm{ha}$ at absolute values of deviation of 7.2-7.3 times less compared to the control variant. Receipt of $\mathrm{P}_{2} \mathrm{O}_{5}$ was provided by the content of $\mathrm{P}_{2} \mathrm{O}_{5}$ in by-products. The removal of $\mathrm{P}_{2} \mathrm{O}_{5}$ by the main products was 2.39-2.45 times lower. The limits of the interval range and the limits of the typical values of $\mathrm{P}_{2} \mathrm{O}_{5}$ removal were 2.162.67 and 2.30-2.45 times smaller compared to the organo-mineral fertilizer system, which affected the level of $\mathrm{P}_{2} \mathrm{O}_{5}$ balance, which was negative and was characterized by the intensity of the balance $\mathrm{lb}<100 \%$ and did not exceed $50 \%$. The balance capacity under the organic fertilizer system was 3.46-3.82 times lower, as well as the interval amplitude and normalized typical values. The turnover rate of $\mathrm{P}_{2} \mathrm{O}_{5}$ was 1.94-2.05 times lower, and the value of $B$ was higher than one: $\mathrm{B} \geq 1.33-1.45$, which indicates a low intensity of circulation of $\mathrm{P}_{2} \mathrm{O}_{5}$ in the agrocenosis of short-rotation crop rotation under the organic fertilizer system (table 3 ).

The evaluation of the balance of different models of fertilizer systems in short-rotation crop rotation was performed on the set of paired correlations between the set of features in the matrix correlation field. In the general model of the correlation matrix of paired correlation coefficients $(n=54)$, direct and inverse correlations ( $\mathrm{R}>0.50)$ account for $39 \%$ of interactions. Of these, $39 \%$ are direct strong correlations, $27.8 \%$ are inverse strong correlations, and the ratio between them is 2.5 to 1 in favor of functional (direct) connections, and the connections that stabilize the system (inverse) account for $11,1 \%$. There were $61 \%$ of the total number of functionally insignificant connections $( \pm R<0.50)$.

In the organo-mineral system, the fertilization of strong bonds ( $\pm R>0.5)$ was $44 \%$. Of these, $37 \%-$ functional connections, $7.4 \%$ - stabilizing, inverse, and the ratio of functional and stabilizing connections was 5 to 1 . Relationships insignificant $( \pm R<0.5)$ were $55.6 \%$. In the conditions of the organic system, the fertilization of functional bonds as a whole was $52 \%$; direct action $-35.2 \%$; reverse action $-16.7 \%$ at a ratio of 2.1 to 1 . Non-essential connections as in the previous case was $48.2 \%$.

According to the fertilizer model, the yield of k.o. and the balance capacity $\mathrm{P}_{2} \mathrm{O}_{5}$ correlate at the level of direct strong correlation $\left(R=0.87-0.96 \pm 0.02 ; R_{2}=0.76-0.92\right)$, and per unit of output growth $k$. and the main products account for an increase in the capacity of the balance of $\mathrm{P}_{2} \mathrm{O}_{5} 7.63-10.7 \mathrm{~kg}$. In this case, the speed of rotation $\mathrm{P}_{2} \mathrm{O}_{5}$ and crop rotation productivity at the output of k.o. and the main product correlates with each other at the level of weak correlation.

It is established that a direct correlation is established between the $\mathrm{P}_{2} \mathrm{O}_{5}$ balance capacity and the output of the main product in 5-field grain-row crop rotation according to the general model at the level of strong correlation, and the unit of phosphorus balance capacity growth is $0.008 \mathrm{t} / \mathrm{ha}$ of the main product yield.

4. The regression equation between the capacity of the balance of phosphorus, nitrogen and the yield of the main product in the grain-row 5-row crop rotation under different fertilizer systems

\begin{tabular}{|c|c|c|}
\hline Correlation parameters & Regression equation & $\begin{array}{c}\text { Correl } \\
\text { ation } \\
\text { coefficient }\end{array}$ \\
\hline \multicolumn{3}{|c|}{ General model } \\
\hline Balance capacity $-\mathrm{P}_{2} \mathrm{O}_{5}, \mathrm{~kg}$ : main products, $\mathrm{t} / \mathrm{ha}$ & $y=3,64+0,008^{*} x$ & 0,65 \\
\hline Balance capacity- $\mathrm{P}_{2} \mathrm{O}_{5}$ : balance capacity $\mathrm{N}, \mathrm{kg} / \mathrm{ha}$ & $y=524,2+1,14^{*} x$ & 0,67 \\
\hline \multicolumn{3}{|c|}{ Organo-mineral fertilizer system (control) } \\
\hline Balance capacity $-\mathrm{P}_{2} \mathrm{O}_{5}, \mathrm{~kg}$ : main products, $\mathrm{t} / \mathrm{ha}$ & $y=-8,76+0,08^{*} x$ & 0,95 \\
\hline Balance capacity- $\mathrm{P}_{2} \mathrm{O}_{5}$ : balance capacity $\mathrm{N}, \mathrm{kg} / \mathrm{ha}$ & $y=-275,2+6,03^{*} x$ & 0,65 \\
\hline \multicolumn{3}{|c|}{ Organic fertilizer system } \\
\hline Balance capacity $-\mathrm{P}_{2} \mathrm{O}_{5}, \mathrm{~kg}$ : main products, t/ha & $y=0,87+0,07^{*} x$ & 0,65 \\
\hline Balance capacity- $\mathrm{P}_{2} \mathrm{O}_{5}$ : balance capacity $\mathrm{N}, \mathrm{kg} / \mathrm{ha}$ & $y=242,9+7,62^{*} x$ & 0,49 \\
\hline
\end{tabular}

The capacity of the phosphorus balance determines the yield of the main product by $64 \%$. There is a direct correlation between the capacity of the phosphorus and nitrogen balance at the level of strong correlation, and the unit of growth of the phosphorus balance is the increase of the nitrogen balance capacity by 1.15 units (Table 4 ).

The organo-mineral fertilizer system also shows a direct correlation between the phosphorus balance capacity and the yield of the main product at the level of strong correlation, and 0.08 units of the output of the main product per unit growth of the balance capacity. The capacity of the phosphorus balance determines the yield of the main product by $90 \%$. A direct strong correlation was found between the phosphorus-nitrogen balance capacity, and 6.03 units of nitrogen per unit of phosphorus growth capacity growth (Table 3). 


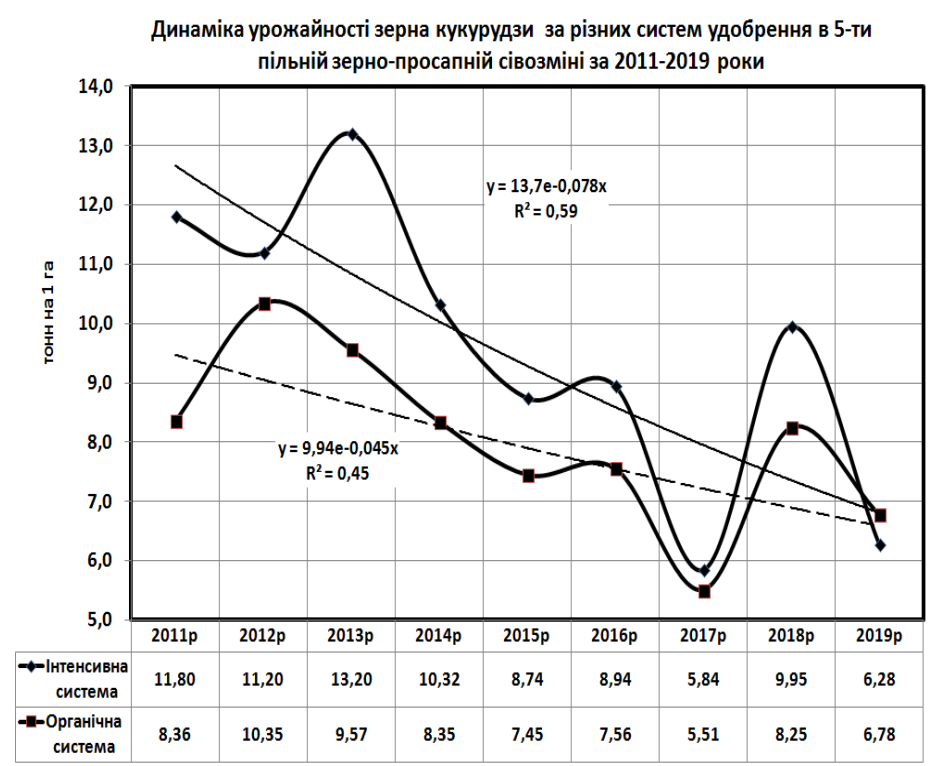

Fig. 1. Dynamics of yield of winter wheat and spring barley depending on the fertilizer in the grainrow 5-field crop rotation for 2011-2019

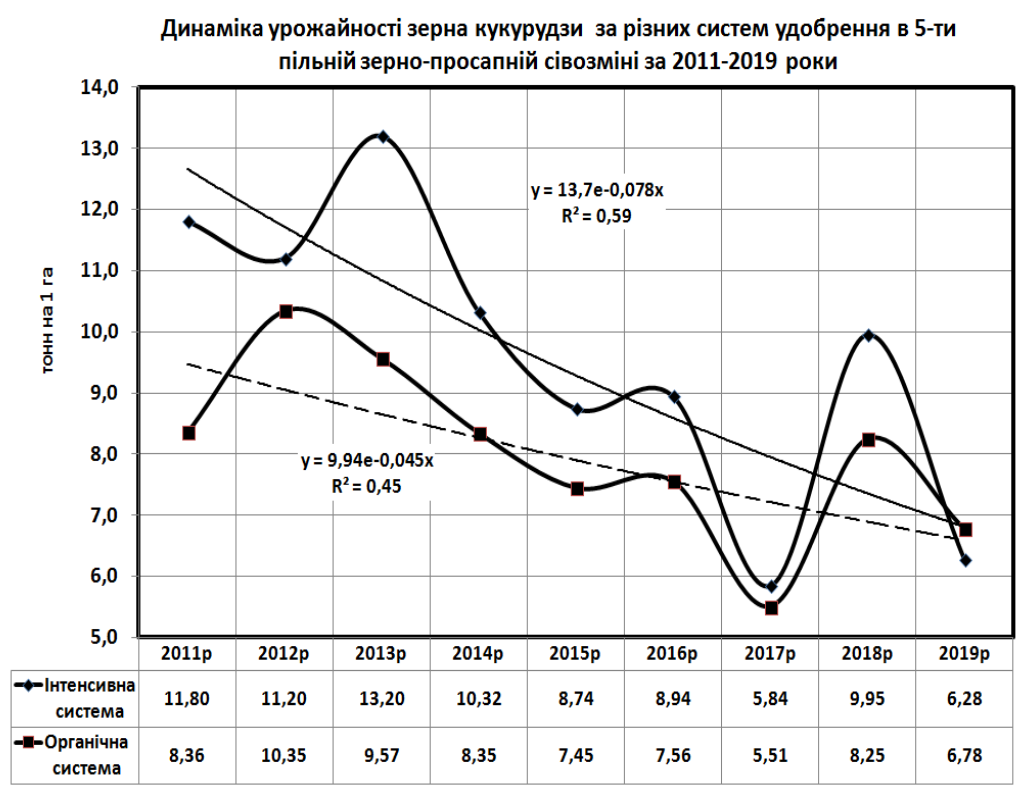

Fig. 2. Dynamics of corn yield per grain depending on the fertilizer in the grain-row 5-field crop rotation for 2011-2019

Under the organic fertilization system, the relationship between the capacity of the phosphorus balance and the yield of the main product was at the level of direct strong correlation, and the unit of growth of the capacity of the phosphorus balance is 0.07 units of growth of the main product. The capacity of the phosphorus balance determines the yield of the main product by $90 \%$. The capacity of the phosphorus balance determines the yield of the main product by $60 \%$, which is 1.5 times less efficient compared to an intensive fertilizer system. A direct correlation at the level of the average correlation was found between the phosphorus and nitrogen balance capacities. Phosphorus balance capacity determines an increase in nitrogen balance capacity of $24 \%$, which is 1.3 times less efficient compared to an intensive fertilizer system.

5. Grain yield parameters for different fertilizer systems (2011-2019)

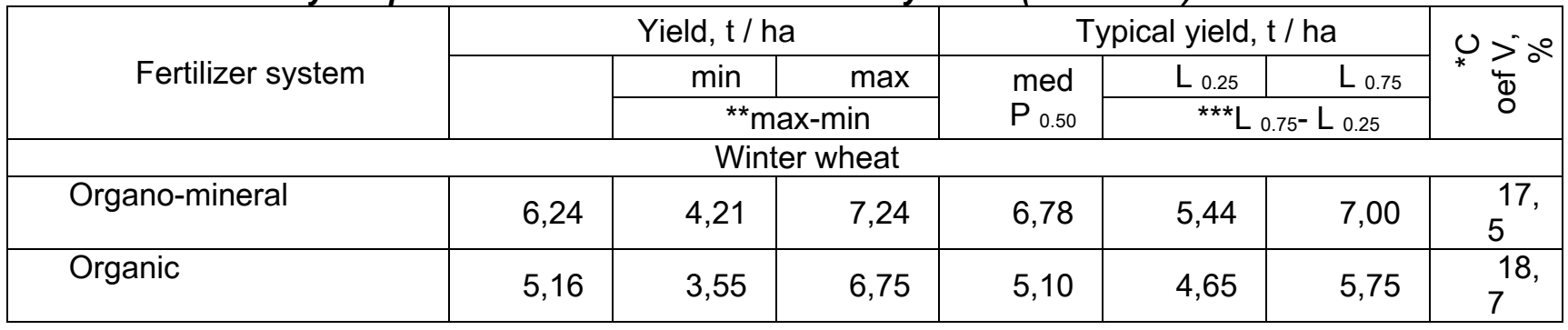




\begin{tabular}{|c|c|c|c|c|c|c|c|}
\hline \multicolumn{8}{|c|}{ Maize } \\
\hline Organo-mineral & 9,99 & 5,84 & 13,2 & 10,1 & 8,84 & 11,50 & $\begin{array}{l}22 \\
4\end{array}$ \\
\hline Organic & 8,10 & 5,51 & 10,4 & 7,96 & 7,50 & 8,98 & $2^{18,}$ \\
\hline \multicolumn{8}{|c|}{ Spring barley } \\
\hline Organo-mineral & 3,63 & 2,55 & 4,49 & 3,74 & 3,10 & 4,18 & $\begin{array}{l}20 \\
3\end{array}$ \\
\hline Organic & 2,85 & 1,45 & 3,81 & 3,00 & 2,08 & 3,52 & $\begin{array}{l}32, \\
5\end{array}$ \\
\hline \multicolumn{8}{|c|}{ Cereals } \\
\hline Organo-mineral & 6,67 & 5,18 & 7,50 & 6,78 & 6,46 & 7,10 & $\begin{array}{l}10, \\
5\end{array}$ \\
\hline Organic & 5,35 & 4,69 & 5,92 & 5,37 & 5,05 & 5,70 & $\begin{array}{l}7,9 \\
5\end{array}$ \\
\hline
\end{tabular}

Note: * Coef. V,\% - coefficient of variation; ${ }^{* * *}$ max-min - amplitude range; ${ }^{* * *} \mathrm{~L} 0.75-\mathrm{L} 0.25$ - quartile scope or normalized scope.

Assessment of the dynamics of grain yields for 2011-2019 under the organic fertilizer system showed that increasing trends were found in winter wheat and barley. Compared with the growth trends of yields of these crops in the organo-mineral system of cultivation, in the organic system the regression coefficients with variable power function for growing barley were 1.5-1.8 times higher, and for growing winter wheat approached each other. When growing corn in the organic system, the trend of yield change was downward, as in the organo-mineral fertilizer system, but in the organic fertilizer system, the yield trend was less downward. In general, grain yields in both organic and organo-mineral cultivation systems were declining, but in the organic fertilization system the decline of the trend was 1.9 times less compared to the intensive fertilization system (Fig. 1, 2).

Statistical evaluation of yield for 2011-2019 showed that the average yield of winter wheat, corn, barley was at the level of $5.16 \mathrm{t} / \mathrm{ha}, 8.10 \mathrm{t} / \mathrm{ha} 2.85 \mathrm{t} / \mathrm{ha}$, and grain in general $-5,35 \mathrm{t} / \mathrm{ha}$, which is $78.5-82.7 \%$ of the organo-mineral fertilizer system (table. 5). The amplitude range $(\max -\mathrm{min}=\Delta)$ of the yield under the organic system of cultivation is shifted towards smaller absolute values of the interval and significantly narrowed compared to the organo-mineral fertilizer system. Similarly, the typical interval values change (L0.25-L0.75). Median yield values for the organic fertilizer system were lower than for the organo-mineral fertilizer system, but as in the latter case, their value tended to yield values for the upper typical value $(L=0.75)$, which indicates its growth in time measurement. The coefficient of variation of grain yield under the organic fertilizer system was lower, except for the yield of barley, compared with the organo-mineral fertilizer system: $7.95 \%$ vs. $10.5 \%$.

\section{Conclusions}

A comparative assessment of the balance of phosphorus in 5-field grain row crop rotation when used as organic fertilizers by-products with saturation of crop rotation with legumes showed that the balance of phosphorus in the organo-mineral fertilizer system was positive $(+17.7 \mathrm{~kg} / \mathrm{ha})$, while the balance of the organic fertilizer system was negative $(-16.6 \mathrm{~kg} / \mathrm{ha})$, and the intensity and capacity of the phosphorus balance of the organic fertilizer system were 2.7 and 3.7 times lower compared to the organo-mineral fertilizer system.

In the organic system of fertilizer between productivity (yield of feed units and main products) and turnover rate and capacity of the balance of $\mathrm{P}_{2} \mathrm{O}_{5}$ revealed significant correlations: with productivity, the relationship was inverted $\left(R=-0.65-0.69 \pm 0.02 ; R_{2}=0.42-0.48\right)$, and with the specified balance indicators straight $\left(R=+0.67-0.69 \pm 0.02 ; R_{2}=0.45-0.52\right)$. Compared with the organo-mineral fertilizer system, the correlations were somewhat weakened, and per unit yield k.o. and the main product is 1.78 and 2.11 times less than the increase in the capacity of the balance of $\mathrm{P}_{2} \mathrm{O}_{5}$.

Phosphorus balance capacity, as an estimated indicator of balance, proved to be a reliable criterion for assessing the interaction with the balance of $\mathrm{N}$ and $\mathrm{CO}_{2}$ balance for different fertilizer systems: a direct correlation was established at the average level: $R=0.53 \pm 0.02 ; R 2=0.23$ for $N$ and $R=0.90 \pm 0.03 ; R 2=$ 0.86 - for $\mathrm{CO}_{2}$, and per unit growth of phosphorus balance capacity accounted for $7.62 \mathrm{~kg} \mathrm{~N}$ and $0.79 \mathrm{t}$ of $\mathrm{CO}_{2}$, which is much higher compared to the organo-mineral fertilizer system and indicates the intensity of phosphorus balance in the organic fertilizer system.

Estimation of grain yield dynamics for 2011-2019 showed that regardless of the fertilization system, increasing yield trends were found in the cultivation of winter wheat and spring barley, and in the cultivation of corn yield trends were declining, but in the organic fertilization system trends were less declining, which made it possible to reach a yield level of about 7.0 t/ha, as in the organo-mineral fertilizer system. In general, grain yields in both organic and organo-mineral cultivation systems were declining, but in the organic fertilizer system the trend was 1.9 times smaller compared to the organo-mineral fertilizer system. The average grain yield under the organic fertilizer system was lower by 1.32 t/ha relative to the organic-mineral system, which was 6.67 t/ha. 


\section{References}

1. Nosko, B. S., Babikin, V. I., Yunakova, T. A., \& Kopot, N. P. (2003). Dynamika struktury fosfatnoho fondu chornozemu typovoho [Dynamics of the phosphate fund structure of typical chernozem]. Bulletin of Agricultural Science, 9(605), 10-15. [In Ukrainian].

2. Nosko, B. S., Babykin, V. I., Burlakova, L. M., \& Kopot, N. P. (2008). Pisliadiia dobryv na fosfatnyi rezhym chornozemiv Ukrainy .[After-effect of fertilizers on the phosphate regime of chernozems of Ukraine]. Bulletin of Agricultural Science, 12(668), 17-22. [In Ukrainian].

3. Nosko, B. S. (2017). Suchasni problemy fosforu v zemlerobstvi i shliakhy yikh rozviazannia [Modern problems of phosphorus in agriculture and ways to solve them]. Bulletin of Agricultural Science, 6(771), 5-12. doi: 10.31073/agrovisnyk201706-01. [In Ukrainian].

4. Ivanina, V. V., Szymanska, N. K., \& Mazur, G. M. (2013). Zakhody biolohizatsii u formuvanni fosfatnoho rezhymu chornozemu typovoho [Biologization measures in the formation of the phosphate regime of typical chernozem]. Bulletin of Agricultural Science, 12(730), 5-12. [In Ukrainian].

5. Nosko, B. S. (2014). Fosfor $v$ zemlerobstvi Ukrainy [Phosphorus in agriculture of Ukraine]. Bulletin of Agricultural Science, 7(615), 14-17. [In Ukrainian].

6. Gulyaev, B. I., \& Patyka, V. F. (2004). Fosfor kak energeticheskaya osnova protsessov fotosinteza, rosta i razvitiya rasteniy [Phosphorus as an energy basis of the processes of photosynthesis, growth and development of plants]. Agroecological Journal, 2, 3-9. [In Russian].

7. Abel, S., Ticconi, C. A., Delatorre, C. A. (2002). Phosphate sensing in higher plants. Physiol. Plant., 115, 18. doi: 10.1034/j.1399-3054.2002. 1150101.x.

8. Dolgopolova, N. V. (2016). Faktory plodorodiya v biologicheskom zemledelii lesostepi Tsentralnogo Chernozemya [Fertility Factors in Biological Steppe Farming Central Black Earth Region]. Regional Bulletin, 2(3), 27-29. [In Russian].

9. Dolgopolova, N. V. (2016). Biologicheskaya sistema zemledeliya i vosproizvodstvo plodorodiya pochvy $v$ lesostepi Tsentralnogo Chernozemya [Biological system of agriculture and reproduction of soil fertility in the foreststeppe of the Central Black Earth Region]. Regional Bulletin, 2(3), 29-32. [In Russian].

10. Deriglazova, G. M., \& Boeva, N. N. (2018). Uluchshennyy balansovyy metod rascheta doz mineralnykh udobreniy dlya effektivnogo ispolzovaniya prirodnogo potentsiala agrolandshaftov [Improved balance method for calculating mineral doses fertilizers for the effective use of the natural potential of agricultural landscapes]. Bulletin of the Kursk Agricultural Academy, 7, 11-14.

11. Kramarev, S. M., Krasnenkov, S. V., Tokmakova, L. N. et al. (2004). Effektivnost ispolzovaniya fosfornykh udobreniy $v$ agrotsenozakh zernovykh kultur [Efficiency of use of phosphorus fertilizers in agrocenoses of grain crops]. Fosfor i kalii u zemlerobstvi. Problemy mikrobiolohichnoi mobilizatsii. Mizhnar. nauk. -prakt. konf. Naukovi dopovidi [Problems of microbiological mobilization. International scientific-practical conference. Scientific reports]. Chernihiv: KP "Printing House". (Vol. 13. pp. 56-65). [In Ukrainian].

12. Medvedev, V. V. (2000). Problema fosforu $\vee$ Ukraini ta shliakhy yii rozviazannia [The problem of phosphorus in Ukraine and ways to solve it]. Bulletin of Agricultural Science, 7, 82-84.

13. Khristenko, A. A. (2001). Problema izucheniya fosfatnogo sostoyaniya pochv [The problem of studying the phosphate state of soils]. Agrochemistry, 6, 89-95. [In Russian].

14. Agbenin, J. O. (2003). Extractable iron and aluminum effects on phosphate sorption in a Savanna Alfisol. Soil Sci. Soc. Am. J., 67, 589-595. doi: 10.2136/sssaj2003.5890.

15. Batten, G. D. (1992). A review of phosphorus efficiency in wheat. Plant and Soil., 146, 163-168. doi: 10.1007/bf00012009.

16. Bolland, M. D. A., \& Gilkes, R. J. (1998). The chemistry and agronomic effectiveness of phosphate fertilizers. Nutrient use in crop production. N.Y.: The Haworth Press. (pp. 139-163). doi: 10.1201/97802037452816.

17. Buehler, S., Oberson, A., Rao, I. M. et al. (2002). Sequential phosphorus extraction of a 32P-labeled Oxisol under contrasting agricultural systems. Soil Sci. Soc. Am. J., 66, 868-877. doi: 10.2136/sssaj2002.0868.

18. Furihata, T., Suzuki, M., \& Sakurai, H. (1992). Kinetic characterization of two phosphate uptake system with different affinities in suspension cultured Catharanthus roseus protoplasts. Plant and Cell Physiol., 33, 1153-1157. doi: 10.1093/ oxfordjournals.pcp.a078367.

19. Abel, S., Ticconi, C. A., \& Delatorre, C. A. (2002). Phosphate sensing in higher plants. Physiol. Plant., 115, 1-8. doi: 10.1034/j.1399 - 3054.2002.1150101.x.

20. Marschner, P., Crowley, D. E., \& Yang, C. H. (2004). Development of specific rhizosphere bacterial communities in relation to plant species, nutrition and soil type. Plant Soil., 261, 199-208. doi: 10.1023/b:plso.0000035569.80747.c5.

21. Marschner, P., Grierson, P. F., \& Rengel, Z. (2005). Microbial community composition and functioning in the rhizosphere of three Banksia species in native woodland in Western Australia. Appl. Soil Ecol., 28, $191-201$. doi: 10.1016/j.apsoil.2004.09.01.

22. Baliuk, S. A., Hrekov, V. O., Lisovyi, M. V., \& Komarysta, A. V. (2011). Rozrakhunok balansu humusu i pozhyvnykh rechovyn u zemlerobstvi Ukrainy na riznykh rivniakh upravlinnia [Calculation of the balance of humus and nutrients in agriculture of Ukraine at different levels of government]. Kharkiv: City Printing House. [In Ukrainian].

23. Ramazanova, N. I., Akhmetova, Z. N., \& Dibirova, A. P. (2007). Biologicheskie osobennosti krugo- vorota azota, fosfora, kaliya, bora i molibdena $v$ agrotsenoze ozimoy pshenitsy. Selskokhozyaystvennaya ekologiya [Biological features of the cycle of nitrogen, phosphorus, potassium, boron and molybdenum in the agrocenosis of winter wheat]. Agricultural ecology. South of Russia: ecology, development, 4, 108-111. [In Russian]. 